\title{
THE REVIEW OF THE 2017 ANNUAL CONFERENCE OF THE ASSOCIATION OF HUMAN RIGHTS INSTITUTES (AHRI) (27 AND 28 APRIL 2017, LEUVEN, BELGIUM)
}

\author{
Aleksandra E. Koneva \\ RUDN University \\ Law Institute \\ 6, Miklukho-Maklaya st., Moscow, Russia, 117198
}

The 2017 Annual Conference of the Association of Human Rights Institutes (AHRI) held at the University of Leuven (KU Leuven) in Leuven (Belgium) from 27 to 28 April 2017 is the one of the leading events among the professional associations uniting international law scholars in human rights field. The conference focused on issues of monitoring compliance with international human rights obligations of States in the activities of universal and regional human rights bodies, particularly UN human rights mechanisms, human rights treaty bodies and regional and sub-regional human rights mechanisms within European, Inter-American and African human rights systems. Within these issues a particular attention was paid to the interaction between universal and regional human rights systems, specifically the role of regional mechanisms in the promotion and protection of human rights and enhancing universal human rights standards enshrined in international human rights treaties.

The paper provides a brief review of the selected reports presented at the conference, which raised a particular scientific interest of the author. The author describes the reports devoted to: 1) factors determining adoption and enforcement of international human rights obligations by States; 2) States' implementation of international human rights norms through the lens of interplay between the international, regional and national levels; 3) the interaction between the universal and European human rights systems (European Court of Human Rights with human rights treaty bodies and special procedures of the UN Human Rights Council).

Key words: Annual Conference of the Association of Human Rights Institutes (AHRI); international human rights law; universal and regional human rights mechanisms; human rights treaty bodies; special procedures of the UN Human Rights Council; European Court of Human Rights

Acknowledgements: The Review is prepared within the President's of the Russian Federation Grant for state support of young scientists - candidates of science (Ph.D.) on the theme "Human rights treaty body system: yesterday, today, tomorrow" MK-1952.2017.6 (head of research - A.E. Koneva).

In today's world there are various professional communities, uniting international lawyers dealing with issues of international human rights protection. During the events organized by these communities, scholars exchange views on various international legal problems in human rights field and discuss cooperation, including joint research projects. Among the most authoritative communities in this field are interest 
groups on International Human Rights Law"1 and on International Business and Human Rights ${ }^{2}$ of the European Society of International Law (ESIL) ${ }^{3}$ and Association of Human Rights Institutes (AHRI) ${ }^{4}$.

Association of Human Rights Institutes is a network of 59 educational institutions from 33 countries in various regions of the world, carrying out research and educational activities in the field of human rights protection. Association's objective is to unite scientists in the field of international human rights law, promote exchange of views and develop cooperation in the indicated area in scientific and educational directions (including conducting joint researches, implementation of joint educational programs, exchange of students, postgraduate students and lecturers).

One of the members of the organization is the European Inter-University Centre for Human Rights and Democratisation (Venice, Italy), uniting 41 European universities into the Venice Consortium, with which RUDN University is developing cooperation through the Department of International Law in the implementation of the joint Master Program "International Protection of Human Rights", implemented by the Consortium of 9 Russian Universities ${ }^{6}$.

One of the key events of the Association is the Annual Conference, which was held at various university-members of the organization since $2007^{7}$. In 2017, the Annual Conference of the Association on the topic "Monitoring compliance with obligations to protect human rights within international and regional organizations" was held from 27 to 28 April 2017 in Leuven (Belgium) at the University of Leuven (KU Leuven). More than 200 scientists and practitioners in the field of human rights, including the author of this article, took place in the event. The conference was held in the form of plenary session and 21 thematic sections.

The main topic of the plenary session was the interaction between universal and regional human rights protection systems, in particular, the role of regional mechanisms in the promotion and protection of human rights and enhancing universal human rights standards enshrined in international human rights treaties. In this regard, particular attention was paid to the resolution of the UN Human Rights Council 34/17 "Regional arrangements for the promotion and protection of human rights" (21 March, 2017) ${ }^{8}$, which, inter alia, contains the request to the Office of the UN

\footnotetext{
${ }^{1}$ Available from: http://www.esil-sedi.eu/node/1102.

${ }^{2}$ Available from: https://igbusinessandhumanrights.wordpress.com/.

${ }^{3}$ The author of this review took part in the 12th Annual Conference of the European Society of International Law, held 7-11 September 2016 at the Riga University of Law, and will be participating in the 13th Annual Conference of the Society on 6-9 September 2017 at the University of Naples Federico II (Naples, Italy).

${ }_{5}^{4}$ Available from: http://www.ahri-network.org.

${ }^{5}$ Available from: https://www.eiuc.org/.

${ }_{7}^{6}$ Available from: URL: http://humanrights.ru/.

${ }^{7}$ Information of previous conferences of the Association available from: http://www.ahri-network.org/ahriconferences.

${ }^{8}$ UN Doc. A/HRC/34/L.26/Rev.1.
} 
High Commissioner for Human Rights (OHCHR) "to expand its cooperation with regional human rights mechanisms by creating, as of 2018, a dedicated programme for the said mechanisms to gain experience in the United Nations human rights system in order to enhance capacity-building and cooperation among them" (para. 7 of the resolution). In addition, the Council requested the High Commissioner to hold in 2019 a workshop on regional arrangements for the promotion and protection of human rights to take stock of developments since the workshop held in $2016^{9}$. Within the framework of the forthcoming event it is planned to organize "a thematic discussion on the role of regional arrangements in the combat against racism, racial discrimination, xenophobia and related intolerance and in the implementation of the commitments in the Durban Declaration and Programme of Action, based on concrete and practical experience of regional mechanisms, in order to share information on best practices, lessons learned and possible new forms of cooperation, with the participation of relevant experts from international, regional, subregional and interregional human rights mechanisms, as well as Members States, observers, national human rights institutions and non-governmental organizations" (para. 8 of the resolution).

All sections of the conference were combined into three thematic blocks, held simultaneously:

1. "Universal system of human rights protection";

2. "Regional organizations and human rights";

3. "International courts and human rights."

Within each section, lasting 1.5 hours, included 3-4 presentations and discussions. Particular interest of the author of the article was raised by presentations within the sections entitled 'States' adoption, implementation and enforcement of international human rights law," "The monitoring and enforcement of international human rights law by UN bodies," "Universal human rights standards in the jurisprudence of the European Court of Human Rights."

Within the framework of these sections, presentations on various aspects of the topics, forming the title of the abovementioned sections, reflecting practical experience of the speaker in the relevant spheres were made. Other presentations contained a brief overview of research conducted by the speaker (goals, methodology, intermediate results, forecasting of project results). The speakers focused on the current state of the following research projects: factors that determine States' adoption and enforcement of international human rights law; states' implementation of international human rights law; invoking legal positions of human rights treaty bodies in the jurisprudence of the European Court of Human Rights (ECtHR) with relation to cases on enforced disappearances; application of legal positions of human rights treaty bodies in the jurisprudence of the ECtHR with relation to cases on racial discrimination; le-

\footnotetext{
${ }^{9}$ UN Doc. A/HRC/34/23.
} 
gal positions of special procedures of the UN Human Rights Council in the jurisprudence of the ECtHR.

It seems necessary to further give an overview of the presentations devoted to the abovementioned research projects.

Presentation of the project "Understanding adoption of international human rights treaties: political regimes and commitment patterns"

This project is performed by three scholars of Masaryk University (Czech Republic). In particular, Katarína Šipulová (Masaryk University, Department of International Relations and European Studies, PhD Candidate in European Studies) presented in her speech reflected the current state of their research work. The authors' main issue deals with ascertaining factors determining adoption and enforcement of international human rights obligations by States. They concluded, that the key aspect is conformity or non-conformity of the State's domestic policy in human rights field with the provisions of international treaties. In case of conformity, a State may express its "serious intent" (authors' term) or "no serious intent" (authors' term) to assume the commitments.

In case of "serious intent," a State assumes the commitment fully or partially, making reservations (for example, non-recognition of the competence of human rights treaty bodies to examine communication or conduct inquiries). In case of "no serious intent," States usually do not assume the commitments at all.

In case of non-conformity of the State's domestic policy in the human rights field with the provisions of international treaties, the State also can express "serious intent" or "no serious intent." In the first case, a State makes reservation that modify the legal effect of the treaty provisions enshrining specific rights ("substantive reservation" - authors' version), that authors equate with refusal to assume the commitment. In the second case, a State assumes the commitment partially ("constrained commitments" - authors' version).

When analyzing the authors' approach it becomes clear that they did not disclose the problem of specific criterions of conformity or non-conformity of the State's domestic policy in the human rights field with international treaties. It seems, that this aspect deserves detailed consideration for the reason that all subsequent results depend on the examination of this issue.

Paying attention to the State obligations to follow the acts adopted by the control bodies of the relevant international treaties, the scholars noted the problematic nature of the States' implementation of their acts providing for amending legislation in comparison to acts providing for remedy to victims of violations (for example, compensation). Among the most notable authors' future research topics is the influence of States' approaches to determination of the legal status of international law in domestic legal system (monism or dualism) on States' adoption and enforcement of international human rights treaties. 
Presentation of the project "Implementation and compliance with human rights law: An exploration of the interplay between the international, regional and national levels"

This research project ${ }^{10}$ is to be carried out in a period from 2015 to 2018 by the group of scientists from four universities: University of Bristol (United Kingdom), University of Essex (United Kingdom), University of Middlesex (United Kingdom) and University of Pretoria (Republic of South Africa) together with Open Society Justice Initiative, which main objective is to examine factors influencing the implementation by nine states (Columbia, Guatemala, Canada, Georgia, Czech Republic, Finland, Cameroon, Algeria, Tanzania) of selected decisions of human rights treaty bodies and decisions of regional judicial and quasi-judicial bodies functioning within European, Inter-American and African human rights protection systems.

The co-executor of the project, Doctor of Law, lecturer at the Faculty of Law of the University of Middlesex A. Donald, in her presentation focused on the factors that determine the reaction of states to the decisions of international human rights courts (full implementation, partial implementation or refusal to implement). One of the main aspects impacting the level of the implementation of the international judicial bodies' decisions (and acts of quasi-judicial bodies) is the existence of various State structures involved in the implementation of these decisions which have different powers and not always use unified approach in the relevant field. But it is obvious that all these structures are elements of one human rights protection system in a State and may ensure its effective functioning only through sustained interaction between each other. Dr. A. Donald pointed to the positions of international bodies with regard to States' decentralized approach to realisation of acts of international human rights mechanisms. These bodies raise concerns that decentralization may cause discrimination and also emphasize that the commitments apply to States Parties in general, not separate government structures. In this regard, they point to the obigations to provide central authorities with powers to control the activities of local authorities.

Projects related to the interaction between the universal and European human rights systems

Employees of the Institute of Law Studies of Polish Academy of Sciences devoted their presentations to the brief analysis of three research projects related to the interaction between the universal and European human rights systems:

1. Invoking universal standards in adjudication practice of the ECtHR: racial discrimination;

2. Invoking universal standards in adjudication practice of the ECtHR: enforced disappearance cases;

3. UN special procedures in the jurisprudence of the ECtHR.

${ }^{10}$ Information about the project available from: http://gtr.rcuk.ac.uk/projects?ref=ES/M008819/1. 
Concerning the first project on the racial discrimination the speaker Dr. Aleksandra Gliszczyńska-Grabias (Senior Researcher at the Poznań Human Rights Centre, Institute of Law Studies of the Polish Academy of Sciences) focused on combating racial hate speeches in the ECtHR practice and pointed to its inconsistent approach with regard to applying the approach of the Committee on the Elimination of Racial Discrimination, which controls the implementation of the 1965 International Convention on the Elimination of All Forms of Racial Discrimination (Convention). In cases of public denial or attempts to justify the Holocaust, the European Court does not refer to the provisions of the Convention and, accordingly, the practice of the Committee, or if it refers to the Convention and the views of the Committee, it supports the Committee's view, pointing to the states' obligation to provide punishment for statements that deny or justify the Holocaust. However, in cases affecting issues of public denial or attempts to justify genocide of other nations, for example Armenians, the European Court chooses another approach. Thus, in case "Perinçek v. Switzerland"11 the ECtHR, considering whether Switzerland's intervention in the applicant's freedom of expression when criminalizing him for denying the Armenian genocide is justified from the point of view of the State's need to follow international obligations in this field, did not support the argument of the respondent State, who referred to the existence of the obligations to criminalize public denial or attempts to justify the Armenian genocide in accordance with the interpretation of Article 4 of the Convention, given in the Committee's general comment ${ }^{12}$. Thus, the ECtHR decided that Switzerland went beyond international obligations, including its obligations under the Convention, because no international treaty clearly establishes an obligation to qualify the denial of genocide as a criminal offense ${ }^{13}$.

In the presentation, dedicated to the second project about the universal standards in the jurisprudence of the ECtHR dealing with enforced disappearance cases, it was mentioned that the Human Rights Committee (controls the implementation of the 1966 International Covenant on Civil and Political Rights) developed the biggest practice in the protection of persons from enforced disappearance, since the Committee on Enforced Disappearances, which monitors the implementation of the 2006 International Convention for the Protection of All Persons from Enforced Disappearance, was created only in 2011 and cooperates with comparatively small number of States parties to the Convention. The author noted that the legal positions of the $\mathrm{Hu}-$

\footnotetext{
${ }^{11}$ European Court of Human Rights. Perinçek v. Switzerland. Application no. 27510/08. 15/10/2015.

12 UN Doc. CERD/C/GC/35, p. 14: "The Committee recommends that public denials or attempts to justify crimes of genocide and crimes against humanity, as defined by international law, should be declared as offences punishable by law, provided that they clearly constitute incitement to racial violence or hatred. The Committee also underlines that "the expression of opinions about historical facts" should not be prohibited or punished".

${ }^{13}$ European Court of Human Rights. Perinçek v. Switzerland. Application no. 27510/08. 15/10/2015, para. 268.
} 
man Rights Committee had a significant impact on the development of the ECtHR's practice. Herewith, unlike the Committee, which qualifies enforced disappearance as torture or degrading treatment in all considered cases, the ECtHR has developed the additional criterions for determining whether the situation of enforced disappearance considered by it is classified as a crime in the form of torture or degrading treatment or not. Furthermore, the ECtHR has also introduced the additional criterions for the recognition of family members of disappeared persons as victims of violations. Thus, the ECtHR refers enforced disappearances to the category of torture or degrading treatment and also recognizes family members of disappeared persons as the victims of enforced disappearances much less than the Human Rights Committee.

Anna Hernandez-Połczyńska (Senior Researcher at the Poznań Human Rights Centre, Institute of Law Studies of the Polish Academy of Sciences), the author of the third research project, talked on the interaction of the special procedures of the UN Human Rights Council with the ECtHR's and identified two types of such cooperation:

1. transmitting to the ECtHR written positions of the special procedures as a third party positions in the case;

2. the European Court invoking the legal positions of the special procedures included in the reports prepared by them, as an additional source of information for establishing the facts of the case, determining the legal content of the affected human rights norms, strengthening the ECtHR's argumentation, and for establishing whether the relevant situation was considered by the special procedures earlier or not ${ }^{14}$.

As an example of the first type of interaction the author referred to the case "AlNashiri v. Poland" 15 , in which the ECtHR uses the argument of the UN Special Rapporteur on the promotion and protection of human rights and fundamental freedoms while countering terrorism, provided in its written position to the Court. The applicant in this case also referred to the position of the Special Rapporteur. Moreover, the ECtHR invited the Special Rapporteur to take personal part in the hearing of the case. The Special Rapporteur's materials helped to establish some facts. The second type of cooperation included examples from the ECtHR's practice, when the documents of the special procedures mandate holders, in particular, the reports of the UN Special Rapporteur on the human rights of migrants served as a reliable source of information about the situation in detention centers in Turkey ${ }^{16}$.

In conclusion the speaker noted the positive aspects of cooperation between the special procedures and the ECtHR, as for the special procedures benefit from rasing awareness about their activities and application of their legal positions at the regional

\footnotetext{
${ }^{14}$ In case if the situation is the subject of the consideration by the Working Group on Arbitrary Detention, the dispute will be declared inadmissible for consideration by the ECtHR.

${ }^{15}$ European Court of Human Rights. Al-Nashiri v. Poland. Application no. 28761/11. 24/07/2014.

${ }^{16}$ European Court of Human Rights. Yarashonen v. Turkey. Application no. 72710/1124. June 2014.
} 
level, and strengthened protection of the rights of victims. For the ECtHR, the practice of the special procedures is a reliable source of legal argumentation and information about the circumstances of the case, examined by the special procedures during their visits to the relevant State.

The author of the article held a number of meetings with the presenters of the abovementioned research projects and exchanged views with them on the role and status of acts of universal human rights mechanisms in national legal systems, on factors that facilitate or, on the contrary, complicate the process of States' implementation of the recommendations of these mechanisms, as well as decisions of international human rights courts.

The next Annual Conference of the Association will be held at the University of Edinburgh (United Kingdom) on 7-8 September 2018, and will be dedicated to the 70th anniversary of the adoption of the Universal Declaration of Human Rights.

\title{
INFORMATION ABOUT THE AUTHOR
}

Aleksandra E. Koneva, Candidate of Legal Sciences, Senior Lecturer, International Law Department, Law Institute, RUDN University.

ORCID: 0000-0002-5338-973X

Contact information

e-mail: koneva_ae@rudn.university

For citation:

Koneva, A. E. (2017) The Review of the 2017 Annual Conference of the Association of Human Rights Institutes (AHRI) (27 and 28 April, Leuven, Belgium). Vestnik Rossiiskogo universiteta druzhby narodov. Seriya: Yuridicheskie nauki [RUDN Journal of Law]. 21(4), doi:10.22363/2313-2337-2017-21-4-588-596

\section{ОБЗОР ЕЖЕГОДНОЙ КОНФЕРЕНЦИИ АССОЦИАЦИИ ИНСТИТУТОВ ПО ПРАВАМ ЧЕЛОВЕКА (27-28 АПРЕЛЯ 2017 Г., ЛЕВЕН, БЕЛЬГИЯ)}

\author{
А.Е. Конева \\ Российский университет дружбы народов \\ Юридический институт \\ 117198, Москва, Россия, ул. Миклухо-Маклая, 6
}

\begin{abstract}
Ежегодная конференция Ассоциации институтов по правам человека, состоявшаяся 27-28 апреля 2017 г. в г. Левен (Бельгия) на базе Левенского католического университета - одно из важнейших мероприятий профессиональных сообществ, объединяющих юристов-международников, занимающихся проблематикой защиты прав человека.

Ключевыми темами конференции являлись вопросы, касающиеся деятельности универсальных и региональных механизмов по правам человека, а именно: правозащитных органов $\mathrm{OOH}$, договорных органов по правам человека и региональных и субрегиональных правозащитных механизмов в рамках европейской, межамериканской и региональных систем защиты прав
\end{abstract}


человека, по осуществлению контроля над выполнением международных правозащитных обязательств государств. В рамках обсуждения данных вопросов особое внимание уделялось взаимодействию универсальной и региональной систем защиты прав человека, в частности, роли региональных механизмов в поощрении и защите прав человека и содействии укреплению универсальных стандартов в области прав человека, закрепленных в международных договорах по правам человека.

В данном обзоре представлен краткий анализ отдельных докладов, которые по мнению автора, вызвали особый научный и практический интерес. В частности, уделяется внимание выступлениям, посвященным: во-первых, факторам, обусловливающим принятие государствами международных обязательств по международным договорам по правам человека; во-вторых, имплементации государствами международных норм по правам человека сквозь призму взаимодействия соответствующих органов на международном, региональном и национальном уровнях; в-третьих, взаимодействию универсальной и европейской систем защиты прав человека (Европейского суда по правам человека с договорными органами по правам человека и специальными процедурами Совета ООН по правам человека).

Ключевые слова: ежегодная конференция Ассоциации институтов по правам человека (AHRI); международное право прав человека; универсальные и региональные правозащитные механизмы, договорные органы по правам человека, специальные процедуры Совета ООН по правам человека, Европейский суд по правам человека

Благодарности: Обзор подготовлен в ходе работы по гранту Президента РФ для государственной поддержки молодых ученых — кандидатов наук по теме «Система договорных органов по правам человека: вчера, сегодня, завтра» МК-1952.2017.6 (научный руководитель — А.Е. Конева).

СВЕДЕНИЯ ОБ АВТОРЕ

Конева Александра Евгенвевна, кандидат юридических наук, ассистент кафедры международного права, Юридический институт, Российский университет дружбы народов.

ORCID: 0000-0002-5338-973X

Контактная информация:

e-mail: koneva_ae@rudn.university

\section{Для цитирования:}

Koneva, A. E. (2017) The Review of the 2017 Annual Conference of the Association of Human Rights Institutes (AHRI) (27 and 28 April, Leuven, Belgium). Vestnik Rossiiskogo universiteta druzhby narodov. Seriya: Yuridicheskie nauki [RUDN Journal of Law]. 21 (4), 588-596. Available from: doi:10.22363/2313-2337-2017-21-4-588-596. 